\title{
Izveštavanje o zaštiti životne sredine u savremenom poslovnom ambijentu (praksa u Srbiji)
}

\section{Environmental reporting in contemporary business environment (practice in Serbia)}

\section{Grozdana Marinković}

Beogradska bankarska akademija, Beograd, Srbija / Belgrade banking academy, Belgrade, Serbia

Rad primljen / Received: 23.12.2020, Rad prihvaćen / Accepted: 07.05.2021.

\begin{abstract}
Sažetak: Pandemija COVID-19 je dovela do progresivnog rasta značaja ekoloških pitanja, socijalnih aspekata i lične sigurnosti. Značaj društveno odgovornog poslovanja kroz izveštavanje o životnoj sredini dodatno je povećan donošenjem Direktive Evropske unije o nefinansijskom izveštavanju prema kojoj određeni broj velikih poslovnih entiteta i kompanija od javnog interesa obavezno sastavlja i objavljivljuje nefinansijske izveštaje o ekološkim i socijalnim uticajima svojih aktivnosti. Cilj rada je analiza prakse obelodanjivanja informacija o ekološkim uticajima i zaštiti životne sredine u Srbiji. Rezultati analize koja je bazirana na javno dostupnim izveštajima odabranih kompanija, najboljih sa aspekta uspešnosti poslovanja, pokazuju da većina ne izveštava o ekološkim performansama i uticajima na životnu sredinu.
\end{abstract}

Ključne reči: zaštita životne sredine, izveštavanje, regulativa, ekološki uticaji, ekološke performanse.

\begin{abstract}
The COVID-19 pandemic has led to a progressive increase in the importance of environmental issues, social aspects and personal safety. The importance of corporate social responsibility through environmental reporting has been further increased by the adoption of the European Union Directive on non-financial reporting, according to which a certain number of large business entities and companies of public interest must to compile and publish reports on environmental and social impacts of their activities. The aim of the paper is to analyze the practice of disclosing information on environmental impacts and enviromental protection in Serbia. The results of the analysis that are based on publicly available reports of selected best companies in terms of business performance, show that most companies do not report on enviromental performance and their impact on the environment.
\end{abstract}

Keywords: environmental protection, reporting, regulation, environmental impacts, environmental performance.

orcid.org/0000-0002-9425-4479, e-mail: grozdana.marinkovic@bba.edu.rs

\section{UVOD / INTRODUCTION}

Pandemija COVID-19 dovela je do značajnih promena u socijalnim i ekonomskim aktivnostima kompanija i direktno prouzrokovala smanjenje obima prodaje i novčanih priliva u najteže pogođenim ekonomskim sektorima. lako kriza kao posledica pandemije nema podjednak uticaj na sve sektore, većina kompanija se, u većoj ili manjoj meri, suočila sa novim izazovima, stavljajući fokus na zdravlje i zaštitu zaposlenih i upravljanje rizicima koji predstavljaju pretnju za poslovanje u aktuelnim okolnostima. Kompanije su usmerene na iznalaženje načina da se izbore sa izgubljenim prihodima i kupcima, nestabilnim izvorima snabdevanja i prekidima $u$ lancima snabdevanja, što je uzrokovalo i određene nestabilnosti na finansijskim tržištima. $U$ cilju redukovanja rizika kojima su izloženi u neizvesnim vremenima, stejkholderima su neophodne pouzdane i prave informacije o finansijskim i ekonomskim 
efektima COVID-19 na poslovanje kompanija, što pred sistem izveštavanja postavlja nove izazove.

Aktuelna pandemija, briga za zdravlje i zaštitu zaposlenih dodatno povećavaju važnost održivog poslovanja i društveno odgovornog poslovanja kompanija. Pored ekonomske odgovornosti pred vlasnicima kapitala, savremeni poslovni ambijent karakteriše i odgovornost menadžmenta u pogledu ekoloških i socijalnih aspekata poslovanja. Korporativna odgovornost je relevantna pretpostavka za dugoročnu poslovnu perspektivu, reputaciju i povećanje kredibiliteta kompanije. Svakodnevno se suočavamo sa problemima izazvanim klimatskim promenama, zagađenjem vazduha i vode, gubitkom biodiverziteta, što ukazuje na važnost obelodanjivanja informacija o uticajima koje poslovne aktivnosti mogu prouzrokovati, merama za njihovo ublažavanje i ekološkim ulaganjima. Pandemija COVID-19 dovodi do rasta relevantnosti pitanja uticaja tehnologija, proizvodnih procesa i procesne opreme kompanija na kvalitet životne sredine, pitanja opšte sigurnosti, zdravlja i bezbednosti zaposlenih. Imajući u vidu progresivni rast značaja navedenih aspekata u novim okolnostima, od suštinske važnosti je procena materijalnosti u pogledu njihovog obelodanjivanja. Suština materijalnosti kao jednog od ključnih principa integrisanog izveštavanja se ogleda u tome da se objavljuju samo ona pitanja, pokazatelji i indikatori koji reflektuju relevantne ekonomske, društvene, ekološke i socijalne implikacije poslovanja (Todorović, 2020).

Izveštavanje o socijalnim aspektima, kvalitetu životne sredine, ulaganjima u zaštitu životne sredine i ekološkoj orijentaciji poslovanja ima za cilj stvaranje relevantne informacione osnove za efikasno upravljanje prirodnim resursima i jačanje društvene odgovornosti kompanija. Računovodstvo zaštite životne sredine i sistem izveštavanja o životnoj sredini pružaju obilje informacija koje su kreatorima regulative iz oblasti zaštite životne sredine, eksternim stejkholderima, ali i stručnoj i široj javnosti važne za donošenje ekonomskih odluka. Uzimajući u obzir relevantnost obelodanjenih informacija za efikasno upravljanje životnom sredinom i analizu ekoloških uticaja, ali i činjenicu da su ekološki aspekti poslovanja još više dobili na značaju u uslovima zdravstvene krize, u radu se ukazuje na važnost izveštavanja o kvalitetu i zaštiti životne sredine i potrebi poboljšanja ekoloških performansi. Jovanović i Ljubisavljević (2017) navode da ekološko računovodstvo, kao poseban pristup prikupljanja, sistematizacije, evidentiranja i izveštavanja o preduzetim ekološkim aktivnostima kompanije, predstavlja informacionu podršku menadžmentu u procesu upravljanja zaštitom životne sredine. Proaktivna uloga menadžmenta i nov pristup upravljanju prirodnim resursima zahteva planiranje, monitoring, evidentiranje i izveštavanje o ulaganjima i efektima koji proizilaze iz projekata ekološkog menadžmenta (Belopavlović i Stevanović, 2012). Prema Izveštaju o zaštiti životne sredine, procenjena ulaganja privrednih sektora u cilju zaštite životne sredine u 2019. godini iznosila su 2,96 milijardi dinara, pri čemu najveći udeo $(86,1 \%)$ beleže kompanije iz sektora energetike i rudarstva (Agencija za zaštitu životne sredine, 2020). Istovremeno, kod kompanija raste svest da njihova dugoročna profitabilnost zavisi od usaglašenosti sa društveno odgovornim poslovanjem i zaštitom životne sredine (Vićentijević i Petrović, 2017).

Cilj rada je analiza prakse obelodanjivanja informacija o ekološkim uticajima i zaštiti životne sredine u Srbiji. Zbog značaja koje ekološko računovodstvo i izveštavanje ima za pojedince, kompanije i društvo u celini, u radu se analiziraju specifičnosti i praksa nacionalnog izveštavanja o zaštiti životne sredine. Rad je strukturiran u četiri dela. Nakon uvoda koji predstavlja prvi deo rada, u drugom delu je predstavljena metodologija i korišćeni podaci u analizi i oceni stepena prezentovanja finansijskih i nefinansijskih informacija o aktivnostima i ulaganjima $u$ zaštitu životne sredine. Akcenat u trećem delu rada je na rezultatima sprovedene analize, dok poslednji deo sumira najvažnije zaključke.

\section{MATERIJALI I METODE / MATERIALS AND METHODS}

Uzimajući u obzir cilj istraživanja, u radu se analiza praksa finansijskog i nefinansijskog izveštavanja u Srbiji, sa posebnim akcentom na izveštavanje o zaštiti životne sredine. Istraživanje je bazirano na analizi napomena uz finansijske izveštaje i godišnjih izveštaja o poslovanju odabranih kompanija koje su u 2019. godini zabeležile najveće poslovne prihode i neto dobitak, i time se svrstale u red najuspešnijih poslovnih entiteta u datom obračunskom periodu. Navedeni izveštaji su javni dokumenti, obelodanjeni i dostupni u Registru finansijskih izveštaja Agencije za privredne registre Republike Srbije.

U cilju ocene nivoa i kvaliteta izveštavanja o zaštiti životne sredine, uticajima primenjenih tehnologija i procesa direktno na životnu sredinu, a indirektno na širu društvenu zajednicu, predmet analize su odabrane kompanije koje posluju u različitim sektorima i čije aktivnosti u većoj ili manjoj meri imaju određene ekološke implikacije. U radu se analiziraju izveštaji 51 kompanije koje su prema Izveštaju o sto naj... privrednih društava Agencije za privredne registre APR (Business Registers Agency of the Republic of Serbia - SBRA) svrstane u grupu najboljih sa stanovišta poslovne uspešnosti (Agencija za privredne registre, 2020). Analiza obuhvata tri kompanije iz 
sektora B - Rudarstvo, 34 kompanije koje posluju u sektoru C - Prerađivačka industrija, šest društava koja pripadaju sektoru D - Snabdevanje električnom energijom, gasom, parom i klimatizacija, i osam iz sektora H - Saobraćaj i skladištenje. Sve analizirane kompanije su prema veličini razvrstane u velika privredna društva.

Zakonska obaveza u pogledu dostavljanja podataka za potrebe informacionog sistema zaštite životne sredine odnosi se na subjekte koji svojim delovanjem ostvaruju uticaj na životnu sredinu. Prema Uredbi o sadržini i načinu vođenja informacionog sistema zaštite životne sredine iz 2009. godine, informacioni sistem sadrži podatke o stanju i pritiscima na životnu sredinu, kao i druge relevantne informacije za potrebe monitoringa stanja životne sredine na nacionalnom nivou. Agencija za zaštitu životne sredine vodi nacionalni registar ispuštanja i prenošenja zagađujućih materija, odnosno velikih izvora zagađivača čije tehnologije, proizvodni procesi i aktivnosti imaju značajne ekološke implikacije (Agencija za zaštitu životne sredine, 2021). Jedinstveni registar izvora zagađivanja životne sredine sistematizuje podatke o izvorima zagađivanja, vrstama, količinama, načinu i mestu ispuštanja zagađujućih materija u vode, vazduh i zemljište, kao i o količinama, vrsti, sastavu i načinu tretmana i odlaganja otpada (Stevanović et al., 2014). Od ukupnog broja poslovnih subjekata koji su obuhvaćeni analizom, trinaest predstavlja velike ekološke zagađivače u Srbiji i uključeno je u nacionalni registar najznačajnijih izvora zagađivanja. Najveći broj (10 kompanija ili približno $77 \%$ ) posluje u sektoru C - Prerađivačka industrija. Jedna kompanija iz sektora B - Rudarstvo je deklarisana kao veliki izvor zagađivanja, dok dve kompanije koje su u obavezi da izveštavaju o uticajima svojih aktivnosti na životnu sredinu posluju u sektoru D.

lako zakonska obaveza nefinansijskog izveštavanja počinje da se primenjuje na izveštaje za 2021. godinu, pojedine kompanije u Srbiji su odavno prepoznale važnost koncepta održivog razvoja i uključile ne samo ekonomske, već i socijalne, kulturne i ekološke aspekte u proces donošenja odluka i izveštavanja. Takve kompanije promovišu održiv i odgovoran razvoj koji je integrisan u poslovnu aktivnost i proizvodne procese. Jedan od ciljeva održivog razvoja odnosi se na adaptaciju i otpornost na klimatske promene, obezbeđenje održive energije i dostupnosti energetskih usluga, kao i smanjenje emisije zagađujućih materija (Ristić, 2021). Imajući u vidu značajan rast društvene i ekološke odgovornosti kompanija, autor istražuje i praksu samoinicijativnog kreiranja i prezentovanja izveštaja o održivom razvoju u analiziranoj grupi privrednih subjekata u Srbiji.

\section{REZULTATI I DISKUSIJA / RESULTS AND DISCUSSION}

Sistem finansijskog izveštavanja u čijoj su osnovi Međunarodni računovodstveni standardi (MRS) i Međunarodni standardi finansijskog izveštavanja (MSFI) ne može u potpunosti da odgovori zahtevima internacionalne regulative koja uređuje pitanja očuvanja i unapređenja životne sredine. MRS 1 Prezentacija finansijskih izveštaja obezbeđuje smernice za jedinstveno finansijsko izveštavanje i poslovno komuniciranje u globalnim okvirima i navodi obavezujući set finansijskih izveštaja javnog karaktera koji ne uključuje kreiranje posebnih ekoloških izveštaja (MRS 1 Prezentacija finansijskih izveštaja, 2021). lako je izveštavanje o ekološkim aspektima poslovanja i ekološkim performansama izvan delokruga profesionalne regulative, kompanije mogu na dobrovoljnoj osnovi obelodaniti i druge izveštaje koji su od značaja za interne i eksterne donosioce odluka. Sastavljanje izveštaja o zaštiti životne sredine je naročito važno za one poslovne subjekte čije tehnologije i proizvodne aktivnosti imaju značajne posledice po okruženje. Potreba za objavljivanjem informacija o generisanom otpadu, reciklaži, merenjima emisije u vazduh i kretanjima u okvirima ili izvan definisanih graničnih vrednosti progresivno se uvećala u novim, pandemijskim okolnostima kada briga za zdravlje i opšte stanje zaposlenih postaje primat.

Godine 2014. doneta je Direktiva 2014/95/EU koja se odnosi na objavljivanje nefinansijskih informacija poslovnih entiteta i informacija o raznolikosti određenih velikih preduzeća i grupa. U skladu sa direktivom, predviđena je obaveza sastavljanja nefinansijskih izveštaja za sve velike kompanije od javnog interesa i matična preduzeća velikih grupa, sa prosečnim brojem zaposlenih više od 500. U cilju povećanja uporedivosti nefinansijskih informacija na području Evropske unije, u nefinansijskom izveštaju se obelodanjuju informacije o politikama, rezultatima i rizicima koji su povezani sa aktuelnim pitanjima poput zaštite životne sredine, socijalnim i kadrovskim pitanjima, poštovanju ljudskih prava, borbi protiv korupcije i podmićivanja, i sl. (European Union, 2014). Nefinansijski izveštaji se mogu objaviti kao samostalan dokument ili kao sastavni deo godišnjeg finansijsko-izveštajnog seta.

Nacionalni Zakon o računovodstvu iz 2019. godine je usklađen sa Direktivom 2014/95/EU u pogledu obaveze objavljivanja nefinansijskih informacija kao dopune tradicionalnim finansijskim informacijama koje su prezentovane u setu redovnih finansijskih izveštaja. Obaveza nefinansijskog izveštavanja se odnosi na izveštaje počev od 1. januara 2021. godine i u skladu je sa društveno odgovornim poslovanjem i ciljevima održivog razvoja. Prema Zakonu o računo- 
vodstvu, obveznici nefinansijskog izveštavanja su velika pravna lica kao društva od javnog interesa koja na dan bilansa imaju više od 500 zaposlenih. Navedene kompanije su u obavezi da sastave i učine javno dostupnim nefinansijski izveštaj sa informacijama relevantnim za razumevanje razvoja rezultata i položaja pravnog lica i rezultata njegovih aktivnosti koje se odnose na zaštitu životne sredine, socijalna i kadrovska pitanja, poštovanje ljudskih prava, borbu protiv korupcije. Reč je o nepristrasnom i objektivnom pregledu razvoja i rezultata poslovanja, sa opisom rizika i neizvesnosti kojima je izloženo (Zakon o računovodstvu, 2019). Analiza razvoja i rezultata poslovanja i položaja određene grupe velikih pravnih lica uključuje finansijske i nefinansijske ključne pokazatelje uspešnosti koji su važni za određenu delatnost.

Imajući u vidu da su predmet analize poslednji javno dostupni izveštaji iz 2019. godine, kao i da se na njih primenjuju odredbe starog Zakona o računo- vodstvu iz 2013. godine koji ne propisuje obavezu prezentovanja posebnog nefinansijskog izveštaja ili njegovog integrisanja u godišnji izveštaj o poslovanju, autor istražuje praksu objavljivanja ekoloških informacija prateći stepen obelodanjivanja u napomenama uz finansijske izveštaje i analizirajući strukturu godišnjeg izveštaja o poslovanju. Napomene uz finansijske izveštaje nastale su kao izraz potrebe za dodatnim informacijama koje nisu prikazane u bilansima, ali čije obelodanjivanje doprinosi potpunom i fer izveštavanju o poslovanju entiteta u određenom obračunskom periodu (Marinković, 2019). Analizom strukture i sadržine napomena koje su sastavni deo kompletnog godišnjeg finansijsko-izveštajnog seta, ocenjuje se nivo obelodanjivanja finansijskih informacija o ekološkim troškovima, dugoročnim rezervisanjima formiranim u cilju unapređenja životne sredine i ekološkim performansama. Stepen obelodanjivanja finansijskih informacija o zaštiti životne sredine u napomenama za analiziranu grupu najbolje rangiranih preduzeća sa stanovišta uspešnosti prikazan je na Grafikonu 1.

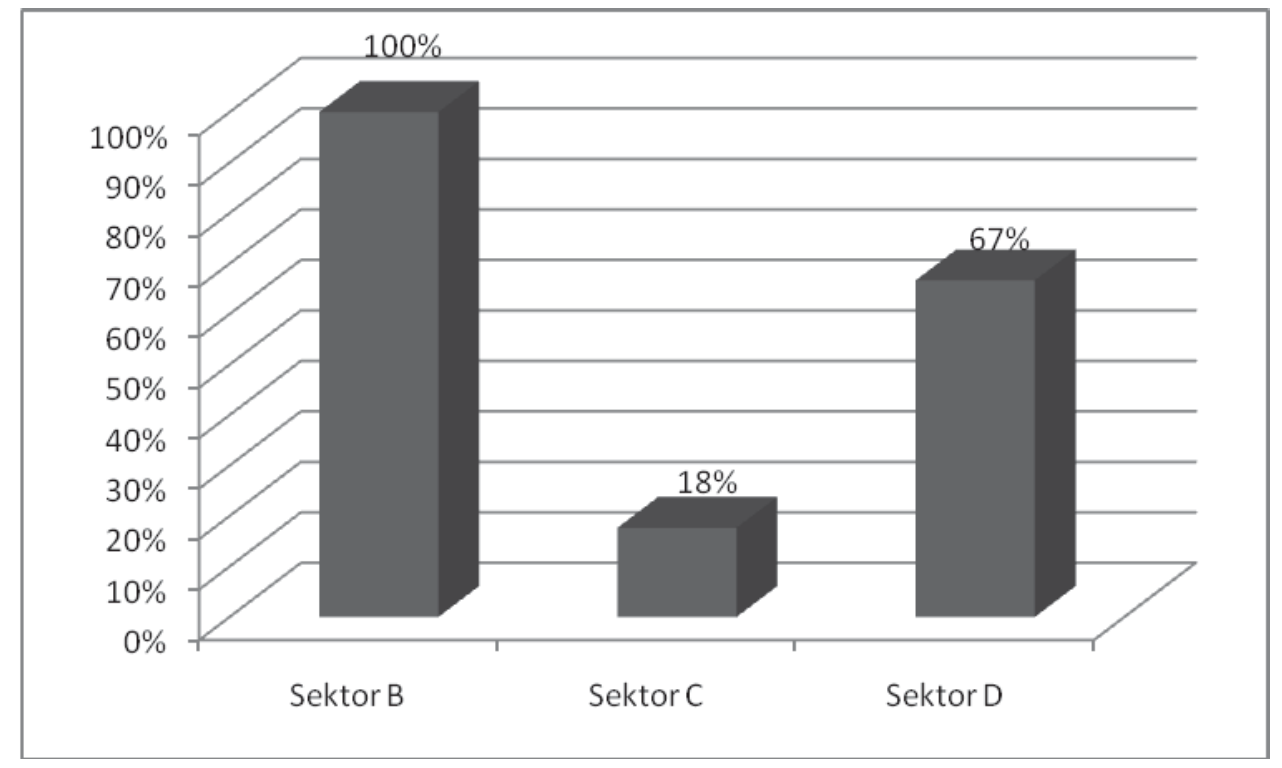

Grafikon 1 - Nivo ekološkog obelodanjivanja u napomenama uz finansijske izveštaje za 2019. (u \%)

Graph 1 - Level of environmental disclosure in the notes to the financial statements in 2019. (\%)

Izvor: Kalkulacija autora na osnovu podataka APR / Source: Authors' calculation based on SBRA data

Detaljna analiza strukture rashoda i dugoročnih rezervisanja pokazuje da većina kompanija obuhvaćenih istraživanjem ne izveštava o izdvajanjima učinjenim u cilju očuvanja i zaštite životne sredine. Od ukupnog broja analiziranih kompanija koje obavljaju delatnost u različitim sektorima, i koje se u skladu sa kriterijumima za razvrstavanje ubrajaju u velike privredne subjekte, svega 13 preduzeća ili $25 \%$ objavljuje ekološke troškove ili rezervisanja za očuvanje životne sredine.
Ako se analiza usmeri na pojedinačne sektore obuhvaćene analizom, sve tri kompanije koje obavljaju delatnost rudarstva informišu o visini dugoročnih rezervisanja za obnavljanje prirodnih bogatstava i očuvanje životne sredine i jedna o visini naknada za zaštitu životne sredine. Preduzeća koja pripadaju sektoru $C$ nemaju iskazana rezervisanja za životnu sredinu, dok se analizom strukture rashoda uočava da značajna većina ne izveštava o ekološkim troškovima. Svega $18 \%$ preduzeća obelodanjuje troškove koji se odnose na odlaganje opasnog otpada, uprav- 
ljanje otpadom i različite aktivnosti za očuvanje životne sredine. Navedeni procenat ukazuje na nizak stepen obelodanjivanja o ekološkim uticajima i aktivnostima usmerenim u zaštitu životne sredine, što je iznenađujuće imajući u vidu da je u analiziranoj grupi preduzeća najveći broj velikih zagađivača upravo iz oblasti prerađivačke industrije. Napomene uz finansijske izveštaje $67 \%$ privrednih subjekata koji obavljaju delatnost u sektoru D - Snabdevanje električnom energijom, gasom, parom i klimatizacija sadrže informacije o ulaganjima u životnu sredinu. Jedno preduzeće iz ovog sektora izveštava o visini formiranih rezervisanja za obnavljanje prirodnih bogatstava, dok četiri preduzeća troškove i naknade na ime zaštite životne sredine svrstavaju u grupu proizvodnih ili nematerijalnih troškova. Nijedno privredno društvo iz sektora $\mathrm{H}$ ne izveštava o ekološkim uticajima svojih aktivnosti ili ulaganjima u cilju očuvanja životne sredine.

Nizak stepen prezentovanja ekoloških informacija u napomenama ne znači da preduzeća nisu ekološki orijentisana i odgovorna prema životnoj sredini niti da nisu prepoznala važnost finansijskog izveštavanja u oblasti zaštite životne sredine. Mali broj kompanija koje izveštavaju o životnoj sredini može biti rezultat činjenice da međunarodna računovodstvena regulativa propisuje minimum informacija koje bi trebalo objaviti u izveštajima i napomenama, a na kompanijama je da procene u kojoj meri će biti transparentni i objaviti druge relevantne informacije koje mogu biti od značaja zainteresovanim stranama za donošenje kvalitetnih odluka. Upravo iz tog razloga, analiza se produbljuje na godišnji izveštaj o poslovanju koji integriše dodatne informacije o poslovnim aktivnostima relevantne za proces odlučivanja, zajedno sa opisom osnovnih rizika i neizvesnosti kojima su izloženi (Zakon o računovodstvu, 2019). Kompanije izveštavaju o kadrovskoj i organizacionoj strukturi, značajnim događajima koji su nastali nakon završetka poslovne godine, ulaganjima u aktivnosti istraživanja i razvoja, planiranom budućem razvoju, kao i izloženosti i upravljanju različitim rizicima.

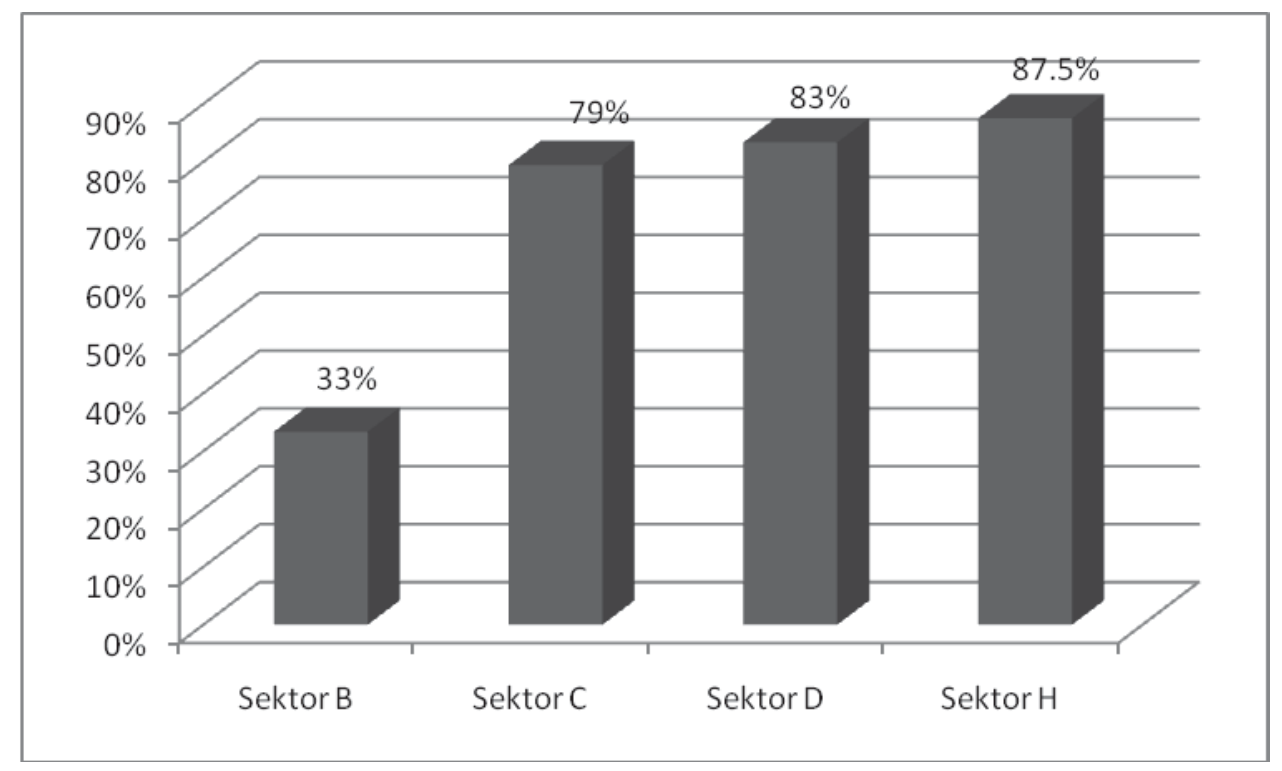

Grafik 2 - Ekološko obelodanjivanje u godišnjem izveštaju o poslovanju u 2019. (u \%)

Graph 2 - Environmental disclosure in the annual business report in 2019 (\%)

Izvor: Kalkulacija autora na osnovu podataka APR / Source: Authors' calculation based on SBRA data

Ekološka odgovornost kompanije može se sagledati kroz odeljak izveštaja koji obuhvata informacije o ulaganjima i aktivnostima koje se odnose na zaštitu životne sredine. Nivo obelodanjivanja informacija o ekološkim projektima, visini ulaganja u čiste tehnologije, merenjima emisija u vazduh, vodu i tlo, kao i o aktivnostima odlaganja i upravljanja otpadom u godišnjem izveštaju o poslovanju nije propisan, i zavisi isključivo od kompanije i njene potrebe ili interesa da navedene informacije učini javno dostupnim. Grafikon 2 pokazuje procenat privrednih društava iz sektora obuhvaćenih analizom čiji godišnji izveštaji o poslovanju sadrže informacije o ekološkim aktivnostima i projektima u cilju unapređenja stanja u oblasti zaštite životne sredine. $U$ odnosu na prezentovanje $u$ napomenama uz finansijske izveštaje, prikazani procenti povrđuju viši stepen obelodanjivanja i veću transparentnost u izveštavanju o životnoj sredini. Za privredne subjekte iz sektora $\mathrm{D}$ i H evidentan je visok stepen transparentnosti u pogledu izveštavanja o očuvanju životne sredine. Sedam preduzeća iz oblasti saobraćaja (ili $87,5 \%$ ) i pet subjekata koja 
obavljaju delatnost u sektoru D (ili 83\%) u izveštajima o poslovanju prezentuju ekološke informacije i implikacije. Najmanji stepen obelodanjivanja primetan je u sektoru rudarstva što se potvrđuje kroz podatak da samo jedno preduzeće izveštava o očuvanju i unapređenju životne sredine. lako je učešće preduzeća iz oblasti prerađivačke industrije koja objavljuju ekološke informacije niži u odnosu na sektor D i H i iznosi približno $79 \%$, relevantna je činjenica da je analizom obuhvaćeno najviše privrednih subjekata iz sektora C. Godišnji izveštaji o poslovanju 27 preduzeća iz prerađivačke industrije sadrže određene informacije o aktivnostima, ulaganjima i merama u cilju zaštite i unapređenja ekološkog okruženja.

lako navedeni procenti ukazuju na dobru praksu objavljivanja informacija o ekološkoj orijentaciji poslovanja, u većini slučajeva kompanije samo formalno navode aspekte društveno odgovornog ponašanja $\mathrm{i}$ nabrajaju sprovedene ekološke aktivnosti. Imajući u vidu da poslovanje kompanija nosi veći ili manji rizik po okruženje, izuzetno je važno osvrnuti se na sadržinu i kvalitet objavljenih nefinansijskih informacija. Godišnjim izveštajima o poslovanju najvećeg broja analiziranih uspešnih kompanija u Srbiji nedostaje kvantikacija, odnosno izveštavanje o visini ulaganja u ekološke aspekte poslovanja, ekološkim parametrima i performansama. Netransparentnost u ekološkom izveštavanju i izostavljanje kvantitativnih indikatora nosi određene rizike imajući u vidu da su donosioci ekonomskih odluka uskraćeni za važne informacije u procesu odlučivanja.

Podizanje svesti o značaju ne samo ekonomskih, već i drugih sfera delovanja uticalo je na pojedine kompanije da samoinicijativno uvedu praksu kreiranja nefinansijskih izveštaja. Pomenute kompanije su ciljeve održivog razvoja uključile u proces poslovnog planiranja i ranije prepoznale važnost objavljivanja društvenih, socijalnih i ekoloških aspekata poslovanja. Imajući u vidu nepostojanje zakonske osnove nefinansijskog izveštavanja za obračunski period korišćen u analizi, u radu se istražuje praksa izveštavanja o održivosti u formi izveštaja strukturiranog prema određenoj međunarodnoj metodologiji. lako direktiva EU o nefinansijskom izveštavanju ne propisuje metodologiju koja će se primenjivati pri kreiranju nefinansijskih izveštaja, veliki broj kompanija u međunarodnim okvirima se oslanja na GRI metodogiju (Global Reporting Initiative) i objavljivanje GRI indikatore koji se odnose na ekonomske performanse, životnu sredinu, zajednicu, radna i ljudska prava i odgovornost za proizvod. Procenu usaglašenosti izveštaja sa GRI smernicama verifikuje nezavisno revizorsko društvo, što predstavlja potvrdu tačnosti navedenih informacija.
Analiza na nacionalnom nivou pokazuje da četiri privedna društva objavljuju izveštaj o održivom razvoju na dobrovoljnoj osnovi u skladu sa najsveobuhvatnijom i najzastupljenijom GRI metodologijom za monitoring aktivnosti u pogledu korporativne društvene odgovornosti. Nefinansijske aspekte poslovanja uobličene u izveštaj o održivom razvoju objavljuje jedna kompanija iz sektora B i tri subjekta iz oblasti prerađivačke industrije. Pet kompanija iz sektora C prezentuje jedinstveni globalni izveštaj o održivosti koji se odnosi na celu grupaciju u okviru koje posluju. Informacije o ekološkoj poslovnoj orijentaciji i ekološkoj održivosti svojih proizvoda i procesa inkorporirane u izveštaj o zaštiti životne sredine prezentuje jedna kompanija iz sektora D i dve kompanije koje obavljaju prerađivačku delatnost.

Društveno odgovorne kompanije kontinuirano stvaraju nova rešenja za održivi razvoj, uz istovremeno povećanje ekonomskog uspeha. Republički zavod za statistiku prati napredak u ostvarivanju ciljeva održivog razvoja u Republici Srbiji za sada na osnovu 83 indikatora koji, između ostalih, uključuju indikatore koji se odnose na održivo upravljanje vodom, pristup održivoj energiji, očuvanje i održivo korišćenje kopnenih ekosistema i njihovog okruženja (Izveštaj o napretku u ostvarivanju ciljeva održivog razvoja do 2030. godine u Republici Srbiji, 2020). Uvođenje obaveze nefinansijskog izveštavanja za određene kompanije u Srbiji u skladu je sa ciljevima održivog razvoja. Poslovni subjekti sa više od 500 zaposlenih će u budućim obračunskim periodima osim tradicionalnih finansijskih informacija prezentovati nefinansijski izveštaj integrisan u godišnji izveštaj o poslovanju. Sva analizirana preduzeća iz grupe najuspešnijih prema ostvarenim finansijskim performansama su razvrstana u velika pravna lica, a 38 kompanija ili približno $75 \%$ ima više zaposlenih u odnosu na minimum koji je definisan za obavezno nefinansijsko izveštavanje. Prema novim zakonskim odredbama usklađenim sa EU direktivom, te kompanije biće deklarisane kao subjekti nefinansijskog izveštavanja koji su u obavezi da pripreme i objave nefinansijski izveštaj.

\section{ZAKLJUČAK / CONCLUSION}

Kriza izazvana pandemijom COVID-19 povećava ekonomsku neizvesnost i podiže svest o zdravlju zaposlenih, socijalnim, društvenim i ekološkim aspektima poslovanja. Imajući u vidu da poslovanje kompanija u većoj ili manjoj meri nosi rizik po okruženje, smanjenje negativnih implikacija proizvodnih procesa i tehnologija na zdravlje ljudi i životnu sredinu postaje primat naročito u aktuelnim kriznim uslovima poslovanja. U radu je sprovedena analiza prakse obelodanjivanja finansijskih i nefinansijskih informacija o eko- 
loškim uticajima i zaštiti životne sredine u grupi najbolje rangiranih kompanija u Srbiji sa stanovišta uspešnosti. Rezultati analize napomena uz finansijske izveštaje pokazuju da 13 kompanija ili $25 \%$ objavljuje finansijske informacije o životnoj sredini u vidu iskazanih ekoloških troškova ili dugoročnih rezervisanja koja su formirana u cilju zaštite životne sredine. Godišnji izveštaji o poslovanju $73 \%$ kompanija obuhvaćenih analizom sadrže informacije o ekološkim aktivnostima i projektima u cilju unapređenja stanja u oblasti zaštite životne sredine, što ukazuje na viši stepen transparentnosti u pogledu obelodanjivanja informacija o životnoj sredini. Dubljom analizom strukture izveštaja ustanovljeno je da najveći broj subjekata ne objavljuje kvantitativne ekološke parametre i indikatore, već opisno nabraja sprovedene aktivnosti ili navode o ekološkoj svesti i društveno odgovornom ponašanju.

Pojedine kompanije su prepoznale važnost održivog razvoja i održavanja balansa između ekonomskog uspeha, društvene odgovornosti i ekološke orijentacije poslovanja. Četiri privredna subjekta ili okvirno $7 \%$ objavljuju izveštaj o održivom razvoju u skladu sa GRI smernicama, pet kompanija prezentuje globalne izveštaje o održivosti, dok tri subjekta kreiraju i obelodanjuju poseban izveštaj o zaštiti životne sredine na dobrovoljnoj osnovi. Uprkos progresivnom rastu značaja održivog poslovanja, rezultati analize pokazuju da većina kompanija, čak i onih koje su integrisale održivu praksu u svoje poslovanje, nije transparentna u vezi sa ekološkim, socijalnim i društvenim uticajima poslovnih aktivnosti. Razlog za to je činjenica da se nefinansijski izveštaji još uvek kreiraju na dobrovoljnoj osnovi u zavisnosti od potrebe ili interesa kompanije da takve informacije obelodani i učini javno dostupnim.

\section{LITERATURA / REFERENCES}

[1] Agencija za privredne registre (2020). Izveštaj o STO NAJ... privednih društava u 2019. godini, https://www.apr.gov.rs/registri/finansijskiizve\%C5\%A1taji/publikacije.2128.html\#645

[2] Agencija za privredne registre, Registar finansijskih izveštaja pravnih lica i preduzetnika, http://www.apr.gov.rs

[3] Agencija za zaštitu životne sredine (2020). Izveštaj o stanju životne sredine u Republici Srbiji za 2019. godinu, http://www.sepa.gov.rs/download//zvestaj _2019.pdf, str. 170.

[4] Agencija za zaštitu životne sredine (2021). Lista PRTR postrojenja, http://77.46.150.218/prtrportal/ lista-prtr-postrojenja-u-srbiji?lang=en

[5] Belopavlović, G., Stevanović, S. (2012). Računovodstveni aspekti zaštite životne sredine, u monografiji: Ekonomski aspekti ekološke politike, Institut ekonomskih nauka, Beogradska bankarska akademija - Fakultet za bankarstvo, osiguranje i finansije, Beograd, str. 359-375

[6] European Union (2014). Directive 2014/95/EU of the European Parliament and of the Council of 22 October 2014 amending Directive 2013/34/EU as regards disclosure of non-financial and diversity information by certain large undertakings and groups, dostupno na: https://eur-lex.europa.eu/ legal-content/EN/TXT/PDF/?uri=

CELEX:32014L0095\&from=EN

[7] Jovanović, D, Ljubisavljević, S. (2017). Ekološko računovodstvo i revizija kao alati upravljanja zaštitom životne sredine, u zborniku radova: Uticaj globalizacije na poslovno upravljanje i ekonomski razvoj Šumadije i Pomoravlja, Univerzitet u Kragujevcu - Ekonomski fakultet, str. 526-527

[8] Marinković, G. (2019). Konvergencija finansijskog izveštavanja u globalnom okruženju, monografija, Beogradska bankarska akademija, str. 18

[9] MRS 1 Prezentacija finansijskih izveštaja, Ministarstvo finansija, dostupno na:

https://www.mfin.gov.rs//upload/media/JgWljh_60 15e1eeed5ad.pdf

[10] Republički zavod za statistiku Republike Srbije (2020). Izveštaj o napretku ostvarivanja ciljeva održivog razvoja do 2030. godine u Republici Srbiji, dostupno na:

https://www.stat.gov.rs/media/5682/izvestaj-onapretku-u-ostvarivanju-ciljeva-odrzivog-razvojado-2030-godine-u-srbiji_web.pdf, str. 9

[11] Ristić, K. (2021). Zelene finansije i ekonomski rast, Ecologica, 28(101), str. 43-49.

[12] Stevanović, S., Belopavlović, G., Lazarević-Moravčević, M. (2014). Obelodanjivanje informacija o zaštiti životne sredine: praksa u Srbiji, Ecologica, 21(76), str. 679-683.

[13] Todorović, M. (2020). Integrisano izveštavanje i upravljanje rizicima preduzeća u uslovima pandemije COVID 19, u zborniku radova: Održivost poslovanja u uslovima virusa korona: Izazovi za reviziju, računovodstvo i finansije, Savez računovođa i revizora Republike Srpske

[14] Uredba o sadržini i načinu vođenja informacionog sistema zaštite životne sredine, metodologiji, strukturi, zajedničkim osnovama, kategorijama i nivoima sakupljanja podataka, kao i o sadržini informacija o kojima se redovno i obavezno obaveštava javnost, Službeni glasnik Republike Srbije, br. $112 / 2009$.

[15] Vićentijević, K., Petrović, Z. (2017). Nefinansijsko izveštavanje u kontektu zaštite životne sredine, Ecologica, 24(87), str. 561-566.

[16] Zakon o računovodstvu, Službeni glasnik Republike Srbije, br. 62/2013 i 30/2018.

[17] Zakon o računovodstvu, Službeni glasnik Republike Srbije, br. 73/2019. 